\title{
Sustainability Infused across the Curriculum at a Minority-Serving Liberal Arts Institution: A Case Study
}

\author{
Lycurgus Muldrow ${ }^{1}$, Brittany Chambers ${ }^{2}$, Mi'Kayla Newell $^{3} \&$ Amy Salter ${ }^{4}$ \\ ${ }^{1}$ HBCU STEM Undergraduate Success Center, Morehouse College, United States \\ ${ }^{2}$ School of Education, Clark Atlanta University, United States \\ ${ }^{3}$ College of Education and Human Development, Georgia State University, United States \\ ${ }^{4}$ HBCU STEM Undergraduate Success Center, Morehouse College, United States \\ Correspondence: Brittany Chambers, School of Education, Clark Atlanta University, United States
}

Received: December 14, 2018

Accepted: June 13, 2019

Online Published: June 17, 2019

doi:10.5430/ijhe.v8n4p1

URL: https://doi.org/10.5430/ijhe.v8n4p1

\begin{abstract}
A critical challenge facing institutions of higher education is the integration of a sustainable energy curriculum into interdisciplinary education. This case study evaluates the campus-wide development and adoption of an interdisciplinary and multidisciplinary sustainability education minor at a small, minority-serving institution. Forty faculty members across 11 academic units participated in the implementation of this initiative. A qualitative analysis of focus group transcripts and course syllabi was conducted to report the processes and findings of the adoption and development of a sustainability curriculum. The focus group results indicated substantial faculty interest and approval of implementing sustainability education at the institution within certain disciplines. Upon the completion of the study it was concluded that the sustainability minor was developed and infused at the college. The implications of this study advance the importance of incorporating sustainability education within all academic disciplines throughout a small, minority-serving institution to increase the presence of African Americans in future careers in energy, green jobs or energy policy/economics.
\end{abstract}

Keywords: sustainable energy education, interdisciplinary curriculum, minority-serving institution, African American STEM education, historically black colleges and universities (HBCU)

\section{Introduction}

Climate change is an issue that humankind can no longer ignore. China and the United States are the two leading contributors to rising $\mathrm{CO}_{2}$ emissions and the largest consumers of fossil fuel resources (Hausfather, 2017). Sustainable energy is broadly defined as energy for current and future generations through the use of renewable and alternative energy sources, while sustainability is defined as an initiative to create and maintain conditions that promote environmental harmony between nature and humankind that will thrive for future generations (Sustainability Curriculum in Higher Education: A Call to Action, 2010; Environmental Protection Agency, 2016). We must educate the future workforce in sustainable energy and sustainability to develop alternative energy technologies that support a sustainable energy economy. Given global interests in recruiting more professionals into sustainability careers, educational efforts should target minorities who are disproportionately represented in STEM fields, like sustainable energy.

This case study examines the development and adoption of a sustainability curriculum across multiple disciplines at a small, minority-serving liberal arts college. According to the Association for the Advancement of Sustainability in Higher Education (AASHE), the top ten "greenest campuses" are all Predominately White Institutions (PWI) (Writer, 2018). Yet, few studies have explored the development and adoption of an interdisciplinary sustainability curriculum at a minority-serving college.

\subsection{The Sustainability Challenge}

A global concern for education curriculum that addresses issues of environmental sustainability emerged around the turn of the millennium with a particular interest in educating minority students and those from low-income communities (Spurring African American STEM Degree Completion, 2016). The National Science Foundation (NSF) 
funded sustainability program was designed to meet this challenge by instilling sustainable energy curriculum into various courses and in a institution-wide Leadership Studies program. This method of infusion was intended to promote environmental justice and push global education goals surrounding sustainable energy across multiple disciplines. Colleges and universities play a fundamental role in addressing global environmental challenges as their education and research can produce long-lasting environmental effects and societal change (Ralph \& Stubbs, 2014). Consequently, liberal arts and minority-serving institutions must incorporate sustainability into each division of student learning as the planet is changing and our natural resources are abating.

\subsection{Liberal Arts Sustainability Education Across the Globe}

A liberal arts education is broadly defined as an education that prepares individuals for diverse contexts and innovative ideas. It is known that a liberal-arts sustainability curriculum increases interest in sustainability degrees and professions (Weissman, 2012). Sustainability curriculums exist within colleges and universities around the world and it has been on the global radar since the formation of the International Environmental Protection Programme by the United Nations in 1978 (Wright, 2004). Within Ireland, there have been several efforts geared toward infusing sustainability curriculums across disciplines, and the country has seen some success. However, similar to the profiles of higher education institutions in the U.S., the schools leading the way in sustainable energy and sustainability are tech schools and those with a predominantly white population.

The global energy crisis cannot be effectively addressed from the perspective of only STEM disciplines, nor can future leaders hope to transform the world's energy systems without a broad, diverse approach. Building a more sustainable future for the next generation of global citizens is the responsibility of every country. (Besong, 2017). The University of Limerick has led the way for sustainability in higher education in Ireland as the Regional Centre of Expertise (Besong, 2017). Their efforts encouraged other institutions to join the sustainability challenge by promoting interdisciplinary education and encouraging ways to preserve the planet. Sustainable energy is an interdisciplinary and multidisciplinary subject that requires an approach from all academic divisions. The goal of developing a sustainable energy curriculum has two objectives: 1) the infusion of sustainable energy and sustainability curriculum in courses, and 2) the development of sustainable energy and sustainability leaders and advocates at the institution. This case study explores the implementation of sustainability curriculum at an institution that serves one of the most underrepresented minorities (URM) in STEM- African Americans.

\subsection{The Lack of Diversity in Sustainability Education}

The negative effects of climate change have disproportionately impacted communities of color and low-income people. The Environmental Justice Movement prioritizes exposing and educating these groups on climate change and sustainability to address this disparity (Carlos, Garibay, Ong, \& Vincent, 2016). A large gap exists in the proportion of people of color in STEM fields across all disciplines, with African Americans making up only seven percent of the sustainability workforce (Jackson, 2017). Thus, national failure to nurture scientific talent within this sector results in projections of an increasingly diminished national pool of sustainability professionals and a degrading environmental future for low-income communities (Jackson, 2017).

A minority-serving college was tasked with providing a transformative interdisciplinary education for undergraduate students, which includes scientific, social, and economic factors that shape sustainability outcomes. This sustainability program broadly aimed to provide students throughout the entire institution with an opportunity to learn about sustainability and sustainable energy. Within this aim, the program sought to encourage STEM and non-STEM majors to consider sustainability career paths. This case study will investigate the following questions:

What is the effect of the development and adoption of a sustainability program on faculty members at a minority-serving, college?

The National Science Board's commitment to Building a Sustainable Energy Future and recommendations for research and practice (leadership, global cooperation, research and development, energy education and the workforce, energy awareness and action, and policy development) (National Science Foundation, 2009) framed our research question. This case study of the sustainability program broadly explores the development and adoption of a sustainability curriculum and its influence on faculty at liberal arts, historically black college and university (HBCU). Our investigation begins with an overview of the research context, then moves into a description of the professional development and curriculum innovation. Finally, we discuss challenges that were met and the implications for future research on infusing sustainability in courses for STEM and non-STEM majors. The following paragraphs will discuss the procedures used to infuse sustainability across the curriculum through Faculty Professional Development. 


\section{The Research Context}

\subsection{Development and Curriculum Innovation.}

\subsubsection{Faculty Development}

The aim of the NSF-funded program was to create an interdisciplinary sustainability and energy curriculum with a concentration in leadership. The sustainability program was supported top-down and bottom up, from the President and Provost of the institution, to faculty members who had personal projects in sustainable energy, sustainability and relevant environmental studies. Each of these individuals realized the progressive impact an interdisciplinary sustainability curriculum could have on the college and the community. After garnering college-wide support, the planning committee created strategic alliances with major corporations, government agencies, and other programs, like the Piedmont Project (Eisen \& Barlett, 2006). The program's process of curriculum development was modeled after the Piedmont Project in affiliation with the Association for the Advancement of Sustainability in Higher Education (AASHE). The Piedmont Project was launched at Emory University in 2001 to prepare faculty for sustainability immersion at the institution.

The idea of developing an initiative that would foster community learning and interdisciplinary work in sustainability derived from the global need of sustainability work in higher education. Having the support of local institutions that have been working in this academic arena was essential to the development of the program. The sustainability program's approach was centered around the Piedmont project and an initiative supported by the NSF to train and prepare faculty members in sustainable energy and sustainability. The goal of the sustainability program was to infuse sustainability concepts and issues into 11 academic majors being offered at the institution so that a sustainability minor could emerge. The first step involved, two faculty members receiving training in a workshop sponsored by AASHE on how to infuse sustainability across the curriculum. These faculty were trained to be leaders in sustainability curriculum initiatives for the college and they served as the support for other faculty members as they restructured their syllabi. Next, several experts from AASHE who were specialist in helping schools implement sustainability initiatives were hired and worked with the two trained faculty to conduct two consecutive, two-day workshops in 2011 and 2012.

Forty faculty participated in four workshops in which faculty received peer training and evaluation of their individual courses and learned how each course pertains to sustainable energy or sustainability in general. In addition, faculty were given syllabi from similar courses taught at other institutions that infused curriculums with energy, sustainability, and environmental issues. As faculty reconstructed their syllabi during these workshops, they were guided by experienced sustainability professionals. These individuals offered their expertise on how to integrate sustainability into everyday classroom topics, projects, writing assignments and much more. Faculty were involved in an immersive experience that included: defining sustainability, faculty collaboration, touring of a sustainability institute (SouthFace), visiting Power headquarters, reviewing case studies and sustainability syllabi, concept stimulation, and integration initiation.

Upon completing the faculty development workshops, each faculty member was required to submit their final syllabi for review to the Sustainable Energy Committee, which was composed of three faculty from the Division of Science and Mathematics, two faculty from the Division of Humanities and Social Science, two faculty from the Division of Business Administration and Economics, as well as, the director of the sustainability program. The Sustainable Energy Committee was tasked with determining which courses effectively integrated sustainability curriculum within their revised syllabi. The faculty professional development was established around several key processes. The initial process included identifying staff who were interested in sustainability initiatives and then identifying courses and departments where sustainability could be effectively infused. The Sustainable Energy Committee evaluated each course using a standardized rubric created by the committee. Table 1. provides an illustration of the standardized rubric, which originated from another university that had already successfully implemented an interdisciplinary sustainability model. 
Table 1. Rubric for Sustainability Syllabi Review

\begin{tabular}{|c|c|c|c|c|c|c|c|}
\hline \multicolumn{8}{|c|}{ Faculty Name: } \\
\hline $\begin{array}{l}\text { Course } \\
\text { Name } \\
\text { Number }\end{array}$ & $\&$ & $\begin{array}{l}\text { Stated } \\
\text { Objectives } \\
\text { include } \\
\text { sustainabilit } \\
\text { y or energy } \\
\text { (Yes/No) }\end{array}$ & $\begin{array}{l}\text { Stated Goals } \\
\text { Include } \\
\text { sustainability } \\
\text { or energy } \\
\text { (Yes/No) }\end{array}$ & $\begin{array}{l}\% \text { of class } \\
\text { focus on } \\
\text { sustainable } \\
\text { energy issues } \\
\text { (Based on class } \\
\text { time or units }\end{array}$ & $\begin{array}{l}\text { What projects } \\
\text { or papers are } \\
\text { included (if } \\
\text { any) that are } \\
\text { relevant for } \\
\text { sustainable } \\
\text { energy }\end{array}$ & $\begin{array}{l}\text { Grading } \\
\text { System } \\
\text { Specified } \\
(\text { Yes/No) }\end{array}$ & $\begin{array}{l}\% \text { of grade } \\
\text { dependent on } \\
\text { sustainability } \\
\text { issues }\end{array}$ \\
\hline
\end{tabular}

\section{Methodology}

\subsection{Participants}

Participants $(n=40)$ included faculty members at a small, minority-serving liberal arts college. Each faculty member was from one of three academic divisions (e.g., math/science, business administration/economics, humanities/social science), representing various courses.

\subsection{Data Sources}

\subsubsection{Faculty Focus Groups}

The researchers conducted focus groups of 8 to 12 faculty per group to assess faculty perceptions of the adoption of a sustainability curriculum. Each faculty member participated in a one-hour focus group to discuss the development and adoption of the sustainability curriculum. The focus group protocol consisted of 3 semi-structured, open-ended questions. Data from the faculty focus groups were audio taped and transcribed by a researcher for analysis.

The focus group transcriptions were open coded through inductive analysis in search of themes associated with the implementation of sustainability within their discipline. Independently, the research team systematically analyzed the data to identify any emerging themes that were consistent throughout the faculty member's responses. First level codes were created to describe the comments made by the faculty, which included identifying similar or recurring words, ideas and relationships. In addition, second level codes were generated to categorize the first level codes. Second level codes were then translated into major themes, which allowed the researchers to organize the content and construct meaningful components.

Research Subjectivity

Qualitative researchers are aware of their own personal biases which may have an effect on the interpretation of the data being analyzed (Levitt, Bamberg, Creswell, Frost, Josselson \& Suárez-Orozco, 2018). To control for biases two researchers coded the data to ensure a high rating of interrater reliability. After data was analyzed and interpreted the researchers reconciled all of the codes to $100 \%$ agreement. These steps were taken to ensure the validity of the measures and control for potential researcher bias.

\section{Findings}

\subsection{Faculty Outcomes}

Following a qualitative analysis of the faculty focus groups, emerging themes were identified. The faculty member's comments and suggestions surrounding the sustainability curriculum were coded into 6 first level codes including: communication, projects, personnel, student's induction, praises and process concerns. These six codes were then organized into three second level codes: process comments, outcome comments and supportive comments. In this section, we review the emerging themes which offer a description of faculty perceptions regarding the implementation of sustainability and sustainable energy curriculum within their specific discipline. Table 2. provides an illustration of sample quotes and codes translating into the four identified themes.

Theme 1: Student Progress

Faculty made comments concerning the perceived changes in student behaviors after being exposed to sustainability curriculum and one faculty member commented that, "I have been able to impact student lifestyles. I have been able to bring changes to their lifestyle like how to conserve energy. I broke down the economics. Quite a few students now take the MARTA to save money, use less air conditioner, and switch off lights. It makes me feel happy to be able to impact their life and decisions." Additionally, comments regarding students' prior knowledge about sustainability and then 
their current understanding of sustainability were made suggesting that students became more knowledgeable about sustainability concepts. Faculty members claimed that, "On the simplest level, my students did not know the difference between renewable/nonrenewable (they) did not know organic/materials/supplement," while another asserted, "Pre students could not name different types of sustainability but after they could differentiate types of sustainability." An increase in student's interest about sustainable topics was alluded to as one professor stated that, "The students are interdisciplinary. My students may like to go over to the lab to see what happened with an experiment if they knew about it."

Theme 2: Interdisciplinary Program Support

The focus groups revealed that faculty were pleased with implementing the sustainability and sustainable energy curriculum. Some faculty were enthused by the curriculum and stated that, "I have fallen in love with sustainability and I am really excited about it and want to know how to put it into other projects," and "I am excited about sustainability and want my peers to be."

Others made comments about the effects the curriculum had on their course asserting that, "One positive, a real positive, is it incorporates different materials into the course." Even when faculty had negative perceptions about their infusion of sustainability into the course they still demonstrated support for the curriculum by stating that they would like to try again, "First semester was not as successful as (I) would have liked...I needed to have the 2nd semester ..this semester." This reflection on the development of the sustainable energy curriculum, brought a broader appreciation and understanding of the development of inclusive sustainability education.

Theme 3: Collaboration

Faculty in this study expressed a desire to collaborate and stay connected with other program participants. They recommended the use of other online resources to stay connected, "We could use a Wiki Page, or community working spaces on line. Indirectly see what we are doing." In addition, faculty members suggested "... a list of the fellows, their fields, and emails," and "... a discussion folder" to help further collaboration with other faculty members. Moreover, faculty suggested sharing their work as a means to review what other disciplines are working on, "It is not very obvious to know what everyone else is doing. We could have a list of faculty about what each are going to do..."

In the evaluation of the syllabi it was apparent that some of the faculty struggled to incorporate sustainability into their discipline (e.g., Music and French) whereas others expressed no difficulties at all (e.g., physical science), "Did not have any problems. Already have it in (my discipline)." Furthermore, one faculty member noted that, "It would be helpful to know what everyone else is doing so we could work together." Providing outlets for faculty to stay connected and providing an environment that facilitates collaboration could work to resolve communication issues and would allow faculty to support each other's efforts and current projects.

Theme 4: Communication

The most discussed process comments broadly related to problems with communication and feedback from program participants and communication difficulties between the program participants and the program manager. Faculty expressed how difficult it was to receive feedback on assignments stating, "One problem is I send in assignments to (the) program and never hear back." Faculty members were communicated with through mass emailing which generated confusion and did not provide the appropriate guidance for faculty members. They expressed issues with mass emailing asserting that "We are sent emails a lot, but the emails are not clear. The content of the emails needs to be clearer and the subject of the emails needs to be clear. We sometimes get multiple emails with the same subject line, but they are for different things. It is easy to ignore new information when the subject line for the emails are not changed." Furthermore, concerns about the program's success when there is a lack of communication arose. However, several suggestions to overcome these communication issues were made. Faculty recommended using their personal emails to communicate as opposed to sending out mass emails. One faculty member claimed, "Problems with mass mailing is that we are bombarded with them. You become immune to them. We need something that is specific to us like a wiki page." Despite the communication issues that arose most of the faculty were pleased with the implementation of sustainability into their courses and demonstrated support for the new sustainability and sustainable energy curriculum. 
Table 2. Sample quotes and codes translated into themes

\begin{tabular}{|c|c|c|c|}
\hline Sample Quote & First level code & Second level code & Theme \\
\hline $\begin{array}{l}\text { "Problems with mass mailing is } \\
\text { that we are bombarded with them. } \\
\text { You become immune to them. We } \\
\text { need something that is specific to } \\
\text { us like a wiki page." }\end{array}$ & $\begin{array}{l}\text { Comments for how to } \\
\text { improve communication }\end{array}$ & Process comments & Communication \\
\hline $\begin{array}{l}\text { "It would be helpful to know what } \\
\text { everyone else is doing so we could } \\
\text { work together." }\end{array}$ & $\begin{array}{l}\text { Comments for lack of } \\
\text { communication among } \\
\text { program participants }\end{array}$ & Process comments & Collaboration \\
\hline $\begin{array}{l}\text { "I have fallen in love with } \\
\text { sustainability and am really excited } \\
\text { about it and want to know how to } \\
\text { put it in (other project)." }\end{array}$ & $\begin{array}{l}\text { Comments } \\
\text { praise }\end{array}$ & Outcome comments & Support \\
\hline $\begin{array}{l}\text { "On the simplest level, my students } \\
\text { did not know the difference } \\
\text { between renewable/nonrenewable } \\
\text { (they) did not know } \\
\text { organic/materials/supplement." }\end{array}$ & $\begin{array}{l}\text { Comments related to } \\
\text { students }\end{array}$ & Outcome comments & Student progress \\
\hline
\end{tabular}

\section{Discussion}

This case study analysis considers the implementation of interdisciplinary sustainability education across disciplines and the impact on faculty members at a minority-serving, liberal arts college. The approach that has been considered the most effective to addressing sustainability issues is centered around interdisciplinary work in academia (Besong, 2017; Sterling, 2014). According to the NSF, the components of this interdisciplinary sustainability approach should include leadership, global cooperation, research and development, energy education and the workforce, energy awareness and action, and policy development (National Science Foundation, 2009). Each component contributes to building sustainability professionals and change-agents in the field to promote a better planet for future generations. In response, 40 faculty at the institution implemented sustainability across 25 different courses through developing and adopting a sustainable energy and sustainability curriculum.

\subsection{The Development}

The syllabi and focus group data revealed there were some highlights and challenges that came with developing interdisciplinary work across 25 courses in 11 academic disciplines. The assessment of focus group statements by faculty revealed a generally positive attitude toward student progress and support for the program. These findings also provided implications that there is a positive relationship between interdisciplinary and multidisciplinary sustainability curriculum and students perceived behaviors and an increased understanding of sustainability. Some courses (e.g., physical science) easily infused sustainability within their curriculums because their courses more closely aligned with the NSF standard of sustainability curriculums. For example, an introductory course in physical science integrated an entire sustainability unit within their course which allowed for students to look at sustainable energy topics, as well as, other topics that contribute to the understanding of sustainability work. On the other hand, other courses (e.g., music) had a more difficult experience. Masterpieces of Music (HMUS 111G, Section 06) did not experience the same level of ease when integrating sustainability. Displaying and showing how and where sustainability would be used in the course was an intimidating task. However, the assistance of sustainability experts and trained faculty aided in the successful development of interdisciplinary syllabi.

\subsection{The Adoption}

The effect of adopting an interdisciplinary and multidisciplinary sustainability program on faculty members at a small liberal arts college was framed by collaboration and communication among faculty and the sustainability program team. After a semester of interdisciplinary learning, faculty reported changes in students' sustainability attitudes and 
behaviors. For example, several students began using public transportation, and two students received an internship with the Department of Energy. Faculty expressed an interest in learning more about careers and degrees related to sustainability and continued expansion of sustainability infusion around campus. The rubric that was used to assess the infusion of sustainability into existing courses was valuable for implementation but lacked clear criteria for the outcomes of syllabi. Therefore, future planning committees should consider creating a rubric that encompasses all the components of a measuring an effective interdisciplinary sustainability curriculum, (e.g., leadership, research, and policy planning).

As it related to long term faculty engagement, the sustainability program planners recognized from the start that sustaining this innovative curriculum at a small liberal arts college could be challenging because maintaining an interdisciplinary curriculum requires ongoing professional development, collaboration. At the conclusion of the first semester, several faculty reported that they needed more time and training in sustainability. These trainings would be devoted to helping faculty create innovative ways to deliver their interdisciplinary work through different effective classroom mediums. The focus group data demonstrated that faculty did not spend time working together throughout the semester, particularly after the development of the curriculum. Faculty communicated an interest in collaborating with other program participants and recommended several forms of online and offline communication such as creating a google doc and a discussion folder. Future studies should create a space for collaboration between faculty members as it could potentially alleviate feelings of uncertainty and confusion when faculty are implementing sustainability concepts into their specific discipline.

The sustainability program exemplifies a method of infusing sustainability into courses without having to increase infrastructure (e.g., new faculty, new courses) -- which is often a problem at small, liberal arts institutions. Developing inexpensive strategies to sustain this initiative is especially relevant for any small liberal arts college due to the budget restrictions often associated with small institutions.

Most notably, the adoption of an interdisciplinary curriculum produced a sustainability minor and student-led organization. The sustainability minor encompassed a variety of courses that were infused with sustainability objectives and standards. The minor is accessible to students in the chemistry department. The sustainability club was organized on campus, led by students, and is still active. The impact of developing and adopting this curriculum had a trickle-down effect from faculty to students and it has left the campus and community with the hope of a greener future.

\section{Conclusion}

Immersing faculty and students into interdisciplinary work in sustainability is essential to creating and maintaining greener initiatives among URM's and the global community. The sustainability program utilized the strengths and resources of the entire institution to create an interdisciplinary and multidisciplinary curriculum that prepares faculty and students to become leaders in the global arena of sustainability. Future research should focus on how to institutionalize faculty development and exposure to sustainability education. A new direction for future studies will be realized based on recent NSF funding obtained by the author to develop a broadening participation research center. This center will focus on the academic success of students, for the continual study of their participation in STEM. Similar research about repeated exposure to sustainability may deepen our understanding of recruitment and retention in sustainability fields, particularly among underrepresented people from all academic disciplines.

\section{Acknowledgements}

Funding provided by the National Science Foundation (1043330 and 1818458) was used to support faculty professional development, implementation of sustainability curriculum, assessment and writing of this paper. We would also like to thank the personnel of sustainability program, Alicia Thomas, and the HBCU STEM-Undergraduate Success (US) Center for their assistance with the collection of data and the writing of this manuscript.

\section{References}

Barlow, R. (2017). Liberal Arts vs. Career Majors: What's an Education For? BU Today. Retrieved from http://www.bu.edu/bostonia/web/liberal-arts-vs-career-majors/

Bekken, B. M. (2012). A Tour of the Earth Sustainability Liberal Education Program: An experiment in integrative learning. Retrieved from https://serc.carleton.edu/integrate/workshops/programs2012/essays/bekkem.html

Besong, F. A. (2017, July). Infusing Sustainability in Higher Education in Ireland: The Green Curriculum Model (GCM) and Dispositions, Abilities and Behaviours (DAB) Competency Framework (Doctoral dissertation, Dublin City University, 2017). School of STEM Education, Innovation \& Global Studies, 1-236. Retrieved from https://hub-media.aashe.org/uploads/FridaBesong_Thesis_July25th_2017_FINAL.pdf. (UMI No. 58210609) 
Boix Mansilla, V., Duraisingh, E.D., Wolfe, C.R., \& Haynes, C. (2009). Targeted assessment rubric: An empirically grounded rubric for interdisciplinary writing. The Journal of Higher Education, 80(3), 334-358. https://doi.org/10.1080/00221546.2009.11779016

Carlos Garibay, J., Ong, P. \& Vincent, S. (2016). Program and Institutional Predictors of Environmental Justice Inclusion in U.S. Post-Secondary Environmental and Sustainability Curricula. Environmental Education Research, 22(7), 919-942. https://doi.org/10.1080/13504622.2015.1054263

Climate Change Indicators: Greenhouse Gases. (2017). Retrieved from https://www.epa.gov/climate-indicators/greenhouse-gases

Cumming, V. (2016). How many people can our planet really support? Retrieved from http://www.bbc.com/earth/story/20160311-how-many-people-can-our-planet-really-support

Doman, L. (2017). EIA projects $28 \%$ increase in world energy use by 2040 . Retrieved from https://www.eia.gov/todayinenergy/detail.php?id=32912

Eisen, A., \& Barlett, P. F. (2006). The Piedmont Project: Fostering Faculty Development Toward Sustainability. Journal of Environmental Education, 38(1), 25-36. https://doi.org/10.3200/JOEE.38.1.25-36

Environmental Protection Agency. (2016). Sustainability. United States. Retrieved from https://www.epa.gov/sustainability

Hausfather, Z. (2017). Analysis: Global CO2 emissions set to rise 2\% in 2017 after three-year 'plateau'. Retrieved from https://www.carbonbrief.org/analysis-global-co2-emissions-set-to-rise-2-percent-in-2017-following-three-yearplateau

Jackson, A. (2017). With Our Health and Billions at Stake, Black People Need to Join the Clean-Energy Revolution Now. Atlanta Black Star. Green For All. Retrieved from https://atlantablackstar.com/2017/04/21/health-billions-stake-black-people-need-join-clean-energy-revolution-n ow/b

Levitt, H. M., Bamberg, M., Creswell, J. W., Frost, D. M., Josselson, R., \& Suárez-Orozco, C. (2018). Journal article reporting standards for qualitative primary, qualitative meta-analytic, and mixed methods research in psychology: The APA Publications and Communications Board task force report. American Psychologist, 73(1), 26-46. https://doi.org/10.1037/amp0000151

Nathan, S. A., \& Loxsom, F. (2016). A Sustainable Energy Laboratory Course for Non-Science Majors. Physics Teacher, 54(7), 420-422. https://doi.org/10.1119/1.4962779

National Science Board. Building a Sustainable Energy Future: U.S. Actions for an Effective Energy Economy Transformation, Building a Sustainable Energy Future. U.S. Actions for an Effective Energy Economy Transformation 1-74 (2009). Arlington, VA.

Sterling, S. (2004). Higher Education and the Challenge of Sustainability: Problematic, Promise and Practice. London: Springer.

Spurring African American STEM Degree Completion. (2016). Retrieved from https://www.ed.gov/news/press-releases/fact-sheet-spurring-african-american-stem-degree-completion

Sustainability Curriculum in Higher Education: A Call to Action. (2010). Association for the Advancement of Sustainability in Higher Education, 1-13. Retrieved from https://oakland.edu/Assets/upload/docs/AIS/Conference/2010_Documents_A_Call_to_Action.pdf.

Weissman, N. B. (2012). Sustainability \& Liberal Education: Partners by Nature. Liberal Education,98(4). Retrieved from https://www.aacu.org/publications-research/periodicals/sustainability-liberal-education-partners-nature

Woods, C. (2007). Researching and developing interdisciplinary teaching: Towards a conceptual framework for classroom communication. Higher Education, 54(6), 853-866. https://doi.org/10.1007/s10734-006-9027-3

Wright T. (2004). The Evolution of Sustainability Declarations in Higher Education. In: Corcoran P.B., Wals A.E.J. (eds) Higher Education and the Challenge of Sustainability. Springer, Dordrecht.

Writers, S. (2018, October 11). The Greenest Universities. Retrieved from https://www.bestcolleges.com/features/greenest-universities/ 


\section{Appendix}

Sustainable Energy Infused Courses

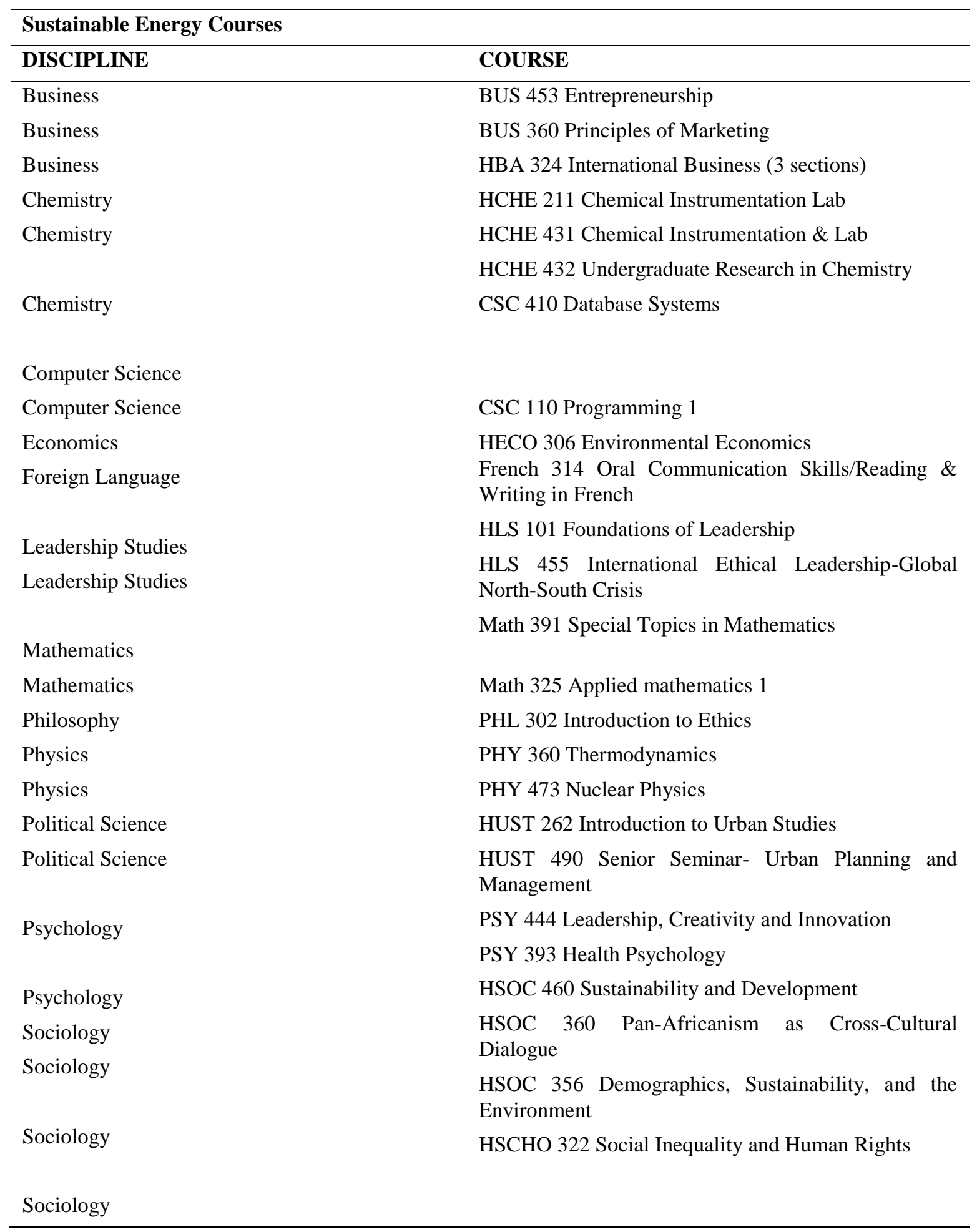

